\title{
Standardization of marketed Ayurvedic formulation, Balaguloochyadi kashayam- physicochemical, microbial evaluation and ephedrine content
}

\author{
Tabassum Asif Khan ${ }^{1 *}$, Rashmi Mallya ${ }^{1}$, Anjali Gohel $^{2}$ \\ ${ }^{1}$ SVKM's Dr. Bhanuben Nanavati College of Pharmacy, Gate no. 1, SVKM Campus, V. M. Road, Vile Parle (W), Mumbai- 400056, India. \\ ${ }^{2}$ Analytical Development Department, PR\& D, Piramal Enterprises Ltd. Mumbai, India.
}

\begin{tabular}{l} 
ARTICLE INFO \\
\hline Article history: \\
Received on: $21 / 06 / 2016$ \\
Revised on: 16/09/2016 \\
Accepted on: 17/10/2016 \\
Available online: $28 / 12 / 2016$ \\
\hline Key words: \\
Herbal formulation, \\
standardisation, \\
Balaguloochyadi kashayam, \\
ephedrine, HPTLC.
\end{tabular}

\begin{abstract}
The present study reports the physicochemical, microbial and analytical (marker based) standardization of an Ayurvedic marketed formulation- Balaguloochyadi kashayam (Rajah Ayurveda). Physicochemical standardization was performed by determining organoleptic properties, $\mathrm{pH}$, specific gravity and total solid content. Total bacterial count and total fungal count studies were performed for microbial standardization. Marker based standardization involved development and validation of a High Performance Thin Layer Chromatography (HPTLC) method for quantitative determination of a chemical marker viz. ephedrine present in Bala, major herb of Balaguloochyadi kashayam as per the standard protocols. The physicochemical and microbial tests were performed in triplicate and average results were calculated. A new, accurate, precise and robust HPTLC method for estimation of ephedrine in Balaguloochyadi kashayam was developed on Camag Linomat-5 using silica gel 60 GF254 as stationary phase and toluene: chloroform: n-propanol: ethanol: formic acid (6: 3: 1: 2: 1, v/v/v/v/v) as mobile phase. The validation studies were performed as per International Conference on Harmonization- Quality (ICH-Q2 (R1)) guidelines. The results of these experiments can be used by manufacturers as a reference for controlling the quality of Balaguloochyadi kashayam formulations prior to release for marketing.
\end{abstract}

\section{INTRODUCTION}

Medicinal plants are the richest bio-resource of drugs of traditional systems of medicine, modern medicines, nutraceuticals, food supplements, folk medicines, pharmaceutical intermediates and chemical entities for synthetic drugs (Gautam et al., 2003). The World Health Organization (WHO) encourages, recommends and promotes traditional/ herbal remedies in national health care programmes because these drugs are easily available at low cost, safe and people have faith in them (Wani, 2007). The use of herbal medicines has increased remarkably in line with the global trend of people returning to natural therapies (Vaidya and Devasagayam, 2007). About $88 \%$ of the world's inhabitants rely mainly on traditional medicine for their primary health care (Kochhar, 1981). Although herbal

* Corresponding Author

Email: tabassum.khan @ bncp.ac.in medicines have been used for thousands of years, the number of reports of people experiencing negative effects caused by the use of herbal drugs has also been increasing. Some cause health problems, some are not effective and some may interact with other concomitantly administered drugs and worsen the condition due to drug contraindication or drug- drug interaction. Standardization of herbal formulations is essential in order to assess the quality of drugs based on the concentration of their active principles and thereby justify the acceptability of herbal formulations in modern system of medicine (Yadav and Dixit, 2008). Standardization of herbal drugs comprises of total information and controls to guarantee consistent composition of all herbals including analytical operations for identification, marker based estimation and assay of active principles. Quality evaluation of herbal preparation is a fundamental requirement of industry and other organizations dealing with ayurvedic and herbal products (Zafar et al., 2005; Patra et al., 2010). 
Balaguloochyadi kashayam is a polyherbal Ayurvedic liquid preparation belonging to the category of kashayams. These are concentrated decoction of herbs which contain water soluble active principles. Balaguloochyadi kashayam is prepared from three medicinal herbs viz. Bala (Sida cordifolia/ Sida rhombifolia/ Sida rotusa), Guduchi (Tinospora cordifolia) and Devdaru (Cedrus deodara). The key ingredient in this medicine is Bala. It is used in the treatment of rheumatoid arthritis, gout, joint inflammation and similar conditions. It is especially useful in pita dominant vata disorders.

This product is also available in the form of tablet. It is manufactured by AVN Ayurveda Formulations Pvt. Ltd, Arya Vaidya Nilayam, Ashoka pharmaceuticals, Aryavaidyasala Kottakkal, Everest Ayurvedic Medicines, Sitaram Ayurveda Pharmacy, Kearala Ayurveda Pharmacy Ltd, Nagarjuna Ayurvedic Group (Ayurvedic medicine information [online]; Ayurpages [online]).

Standardization of Balaguloochyadi kashayam is not reported till date. Hence this study was conducted with the aim to standardize this formulation with respect to its physicochemical properties (organoleptic properties, $\mathrm{pH}$, specific gravity and total solid content), microbial parameters (total bacterial count and total fungal count) and marker viz. ephedrine (phytoconstituent of major herb of Balaguloochyadi kashayam) quantitation by HPTLC method development and validation of the same.

\section{MATERIAL AND METHODS}

\section{Procurement of chemicals}

Balaguloochyadi kashayam of Rajah Ayurveda was purchased from Sarvodaya Ayurved Aushadhi Bhandar, Mumbai. The reference standard ephedrine was purchased from Total Herb Solution (THS), Mumbai. The solvents and chemicals used in the research work were of analytical grade.

\section{Physicochemical tests}

Organoleptic properties

This formulation was evaluated for its organoleptic properties viz. odour, appearance and taste.

\section{pH}

The $\mathrm{pH}$ was determined using a calibrated $\mathrm{pH}$ meter.

\section{Specific gravity}

The specific gravity of formulation was determined using $10 \mathrm{ml}$ specific gravity bottles and calculated using the following formula-

Sp. gravity of liquid (formulation) $=$ weight of $10 \mathrm{ml}$ of liquid/ 10 weight of $10 \mathrm{ml}$ of water/ 10

\section{Total solid content}

This was determined by taking $10 \mathrm{ml}$ of the formulation in porcelain evaporating dish and heating it on an electric water bath at $60-70^{\circ} \mathrm{C}$ and then in an oven at $105^{\circ} \mathrm{C}$ until constant weight of residue was obtained.

\section{Microbial test}

This involved determination of total bacterial count and total fungal count. Each of the microbial experiments was performed in a sterilized laminar air flow (LAF) chamber. This experiment was performed using a sample from a newly opened bottle. The sample stock solution was prepared by taking $10 \mathrm{ml}$ of formulation and making up the volume to $100 \mathrm{ml}$ with Soyabean Casein Digest (SCD) broth. $1 \mathrm{ml}$ of this stock solution was used as test sample for all the microbial tests. Four control petri plates viz. medium control, diluent (negative) control, positive control (bacteria and fungus culture) and environment control were set for each experiment. For total bacterial count, the test samples along with control samples were incubated in Soyabean Casein Digest Agar (SCDA) medium at $35^{\circ} \mathrm{C}$ for 2-3 days. For total fungal count, the samples were incubated in Sabouraud Dextrose Agar (SDA) medium at $25^{\circ} \mathrm{C}$ for 5-7 days.

\section{HPTLC method development Sample preparation}

$20 \mathrm{ml}$ of Balaguloochyadi kashayam formulation was taken in a porcelain evaporating dish and kept on an electric water bath at $70-80^{\circ} \mathrm{C}$ for $2-3 \mathrm{hrs}$ until a dry residue was obtained. Approximately $5 \mathrm{~g}$ of this residue was dissolved in $20 \mathrm{ml}$ of water and transferred to a $250 \mathrm{ml}$ separating funnel. This solution was extracted with ethyl acetate $(50 \mathrm{ml} \times 3$ times $)$ and the ethyl acetate fractions were pooled and filtered through Whatmann filter paper. The filtrate was then evaporated to obtain a dried ethyl acetate fraction using Rotavap vacuum evaporator. This fraction was weighed and dissolved in ethyl acetate for further HPTLC analysis.

\section{Standard preparation}

$2 \mathrm{mg}$ of standard ephedrine was accurately weighed and transferred to a $2 \mathrm{ml}$ eppendorf. The volume was made upto $1 \mathrm{ml}$ with methanol to yield 2000 ppm stock solution.

\section{Mobile phase development and optimisation}

HPTLC method was developed by taking trials of mobile phases using solvents viz. methanol, ethyl acetate, ethanol, butanol, toluene, chloroform, triethyl amine, formic acid, ammonia in different proportions. Reported methods for ephedrine were tried, but modifications in method were required to successfully apply it in sample matrix.

\section{HPTLC chromatographic conditions}

The sample and standard solutions were applied as bands of $8 \mathrm{~mm}$ width with a Camag microlitre syringe on precoated silica gel aluminium plate $60 \mathrm{~F}_{254}(20 \mathrm{~cm} \times 10 \mathrm{~cm}$ with $250 \mu \mathrm{m}$ thickness; Merck). Linear ascending development was carried out in $20 \mathrm{~cm} \times 10 \mathrm{~cm}$ twin trough glass chamber. After development, 
the HPTLC plates were dried in a current of air with the help of an air-dryer. Densitometric scanning was performed with Camag TLC scanner using UV detector (deuterium lamp) in the remission-absorption mode at $254 \mathrm{~nm}$. The slit dimension was kept at $6 \mathrm{~mm} \times 0.45 \mathrm{~mm}$ and scanning speed of $20 \mathrm{~mm} / \mathrm{s}$ was set.

\section{HPTLC method validation}

The optimised method was validated as per ICH Q2 (R1) guidelines for the following parameters (International Conference on Harmonization- Q2 (R1), 2005).

\section{Linearity and range}

The linearity was evaluated in the concentration range of 4-28 $\mu \mathrm{g}$ / band for ephedrine. Peak area versus concentration was subjected to least square linear regression analysis and the slope, intercept and regression value for the calibration were determined. From the calibration plot, the concentration range which gave linear correlation between the peak area and the applied concentration was determined.

\section{Limit of Detection (LOD) and Limit of Quantitation (LOQ)}

The LOD and LOQ for ephedrine marker was determined using following expression: $3.3 \sigma / \mathrm{S}$ and $10 \sigma / \mathrm{S}$ respectively where $\sigma$ is the standard deviation and $S$ is the slope of the calibration curve.

\section{Accuracy}

Accuracy was evaluated through the percent recoveries of known amounts $(80 \%, 100 \%$ and $120 \%)$ of standard ephedrine spiked on sample solution. Percent recovery was calculated using the following equation-

Percent recovery $=[$ Practical recovery $/$ Theoretical recovery $] \times$ 100.

\section{Precision}

Ephedrine in concentration of $20 \mu \mathrm{g} / \mathrm{band}$ was applied seven times on a plate and percent coefficient of variation $(\% \mathrm{CV})$ between the peak area values were calculated after repeating the same experiment three times in a day (intraday precision) and on three different days (inter-day precision).

\section{Specificity}

The method was checked for the presence of any interference peaks of diluent (ethyl acetate) and mobile phase.

\section{Robustness}

Robustness studies were carried out with intentional variation in two chromatographic parameters viz. mobile phase composition and solvent front distance to determine its influence on the Rf value, peak area and peak shape of standard ephedrine. The mobile phase composition was altered by $\pm 0.5 \mathrm{ml}$ of each solvent while solvent front distance was altered by $\pm 10 \mathrm{~mm}$ from the optimized value.

\section{RESULTS AND DISCUSSION}

Physicochemical tests

The results of physicochemical tests are given in table 1 .

Table 1: Physicochemical characterization of Balaguloochyadi kashayam (Rajah Ayurveda).

\begin{tabular}{lll}
\hline Sr. No. & Parameters & Observation* \\
\hline $\mathbf{1}$ & Organoleptic properties & Brown, muddy coloured liquid, \\
& & bitter in taste \\
$\mathbf{2}$ & $\mathrm{pH}$ & $5.513( \pm 0.104)$ \\
$\mathbf{3}$ & Specific gravity & $1.02231( \pm 0.027)$ \\
$\mathbf{4}$ & Total solid content & $6.14 \% \mathrm{w} / \mathrm{v}( \pm 0.093)$ \\
\hline
\end{tabular}

\section{Microbial test}

This formulation was found to comply with the specification limit for total bacterial count i.e. NMT $1 \times 10^{5}$ $\mathrm{CFU} / \mathrm{ml}$ and total fungal count i.e. NMT $1 \times 10^{3} \mathrm{CFU} / \mathrm{ml}$ (Protocol for testing Ayurveda, Siddha and Unani medicines [ONLINE]). The pictures of sample and control petri plates for total bacterial and total fungal count after incubation are given in figure 1.

\section{HPTLC method development HPTLC Method Optimisation}

The optimised chromatographic conditions are mentioned in table 2 .

\section{HPTLC method validation Linearity and range}

The linearity study indicated a linear correlation between the peak area and analyte concentration at a concentration range of 8 to $28 \mu \mathrm{g} /$ band $\left(r^{2}=0.995\right)$.

\section{Limit of detection (LOD) and Limit of Quantitation (LOQ)}

The calculated LOD and LOQ values were found to be $0.05 \mu \mathrm{g} / \mathrm{b}$ and and $0.16 \mu \mathrm{g} / \mathrm{band}$ respectively.

\section{Accuracy}

The result indicated average percent recovery of $81.32 \%$, calculated as mentioned in table 3 .

\section{Precision}

The percent coefficient of variation between peak area values of standard ephedrine after intraday and interday precision studies was found to be $1.205,1.589,1.829$ and $1.205,1.587$, 1.655 respectively.

\section{Specificity}

The method was found to be specific for ephedrine with no interference peak of diluents and mobile phase at the $\mathrm{Rf}$ position of ephedrine. 

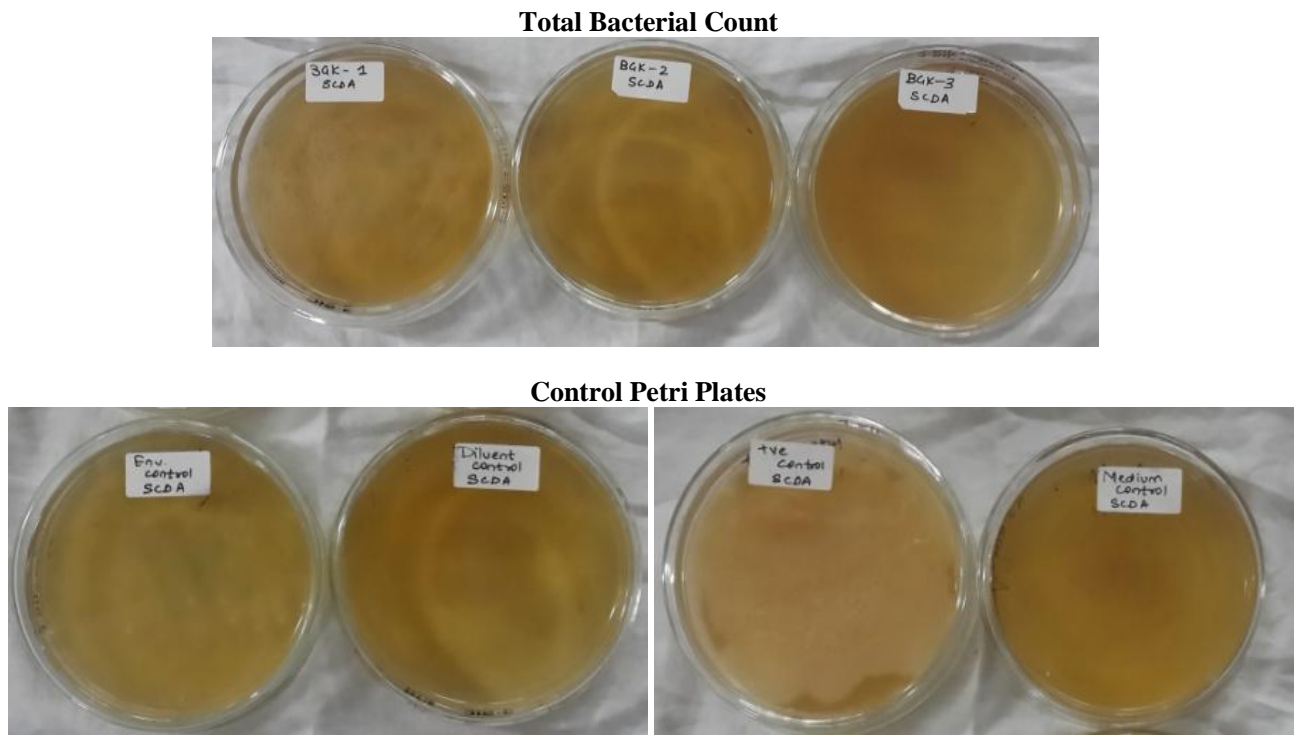

Total Fungal Count

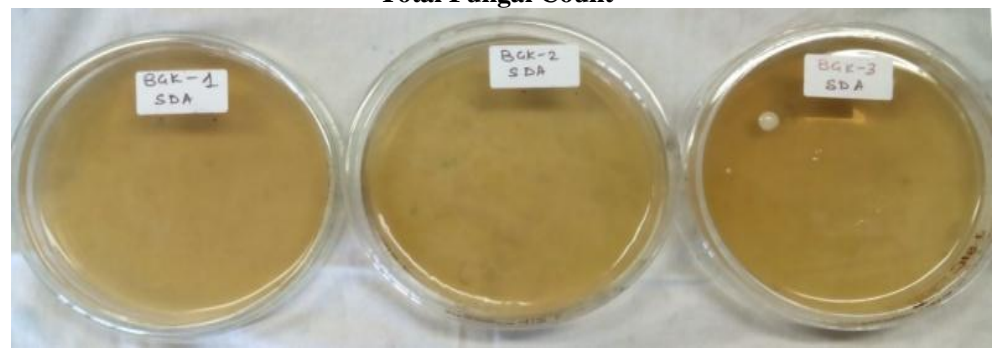

Control Petri Plates

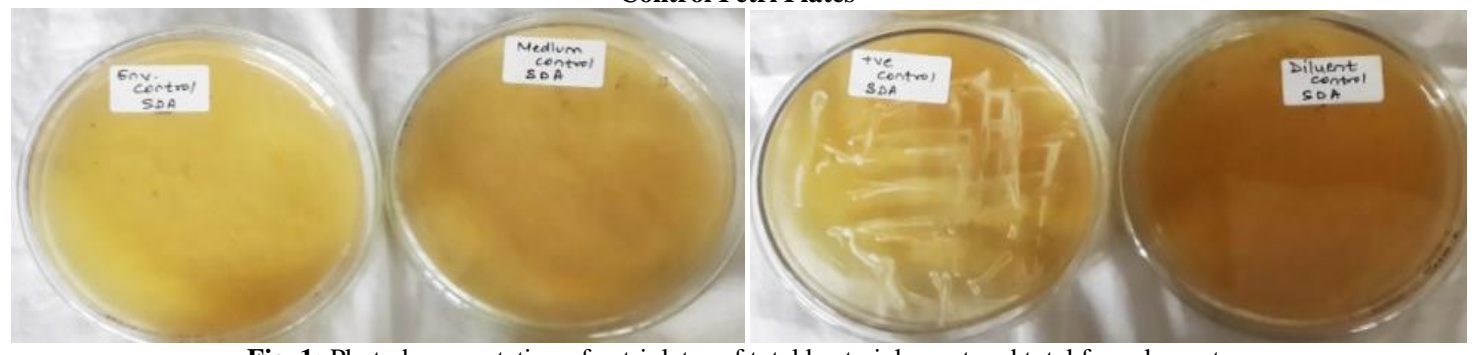

Fig. 1: Photodocumentation of petriplates of total bacterial count and total fungal count.

Table 2: Optimised HPTLC conditions for analysis of ephedrine.

\begin{tabular}{ll}
\hline HPTLC instrument & CAMAG Linomat 5 \\
\hline Stationary phase & Silica Gel $60 \mathrm{GF}_{254}$ \\
Mobile phase & Toluene: Chloroform: n-propanol: Ethanol: Formic acid $(6: 3: 1: 2: 1, \mathrm{v} / \mathrm{v} / \mathrm{v} / \mathrm{v} / \mathrm{v})$ \\
Observed Rf value & $0.17 \pm 0.02$ \\
Band width & $8 \mathrm{~mm}$ \\
Saturation time & No saturation \\
Solvent front distance & $80 \mathrm{~mm}$ \\
Detection lamp & Deuterium \\
Detection wavelength & $254 \mathrm{~nm}$ \\
\hline
\end{tabular}

Table 3: Recovery study of ephedrine (E).

\begin{tabular}{|c|c|c|c|c|c|c|c|c|}
\hline \multirow[b]{2}{*}{ S. No. } & \multirow[b]{2}{*}{$\begin{array}{c}\text { Sample } \\
\text { conc. } \\
\text { ( } \mu \text { g/band) }\end{array}$} & \multirow[b]{2}{*}{$\begin{array}{c}\text { Std. E spiked } \\
(\mu \mathrm{g} / \text { band })\end{array}$} & \multicolumn{3}{|c|}{ Peak Area of- } & \multirow[b]{2}{*}{$\begin{array}{c}\text { Theoretical } \\
\text { recovery } \\
C=(A+B)\end{array}$} & \multirow[b]{2}{*}{$\begin{array}{c}\text { \% Recovery } \\
\text { D*100/C }\end{array}$} & \multirow[b]{2}{*}{$\begin{array}{c}\text { Avg. } \\
\text { \% recovery }\end{array}$} \\
\hline & & & $\begin{array}{c}E \text { in } \\
\text { sample } \\
\text { (A) }\end{array}$ & $\begin{array}{c}\text { Std. E } \\
\text { (B) }\end{array}$ & $\begin{array}{c}\text { Spiked sample/ } \\
\text { Practical recovery } \\
\text { (D) }\end{array}$ & & & \\
\hline 1 & 100 & $12.8(80 \%)$ & 1160.25 & 2282.2 & 2785.1 & 3442.5 & $80.903 \%$ & $81.32 \%$ \\
\hline 2 & 100 & $16(100 \%)$ & 1160.25 & 2738.5 & 3141.6 & 3898.75 & $80.57 \%$ & \\
\hline 3 & 100 & $19.2(120 \%)$ & 1160.25 & 2873.2 & 3327.7 & 4033.45 & $82.50 \%$ & \\
\hline
\end{tabular}




\section{Robustness}

There was no change in resolution with decrease in mobile phase volume of each solvent by $0.5 \mathrm{ml}$, however a reduction in the $\mathrm{R}_{\mathrm{f}}$ value was observed. The bands were not completely resolved and the chromatogram was observed to be distorted with increase in $R_{f}$ value when mobile phase volume of each solvent was increased by $0.5 \mathrm{ml}$. The method was found to be robust with both increase and decrease in solvent front distance by $\pm 10 \mathrm{~mm}$

A summary of all validation parameters is given in table 4 .

Table 4: HPTLC Validation results of ephedrine.

\begin{tabular}{ll}
\hline Parameters & Results \\
\hline Linearity (Regression value) & 0.995 \\
Range $(\mu \mathrm{g} /$ band) & $8-28$ \\
Limit of Detection (LOD) ( $\mu \mathrm{g} / \mathrm{band})$ & 0.05 \\
Limit of Quantification (LOQ) ( $\mu \mathrm{g} / \mathrm{band})$ & 0.16 \\
Accuracy (avg. \% recovery) & $81.32 \%$ \\
Precision- Intraday (avg. \%CV) & $1.541 \%$ \\
Precision - Interday (avg. \%CV) & $1.482 \%$ \\
Specificity for interference of diluent and mobile phase & Specific \\
Robustness for change in solvent front distance & Robust \\
\hline
\end{tabular}

\section{Quantitation of ephedrine in Balaguloochyadi kashayam}

The HPTLC fingerprint of unspiked sample (track 1, 2 and 4) and spiked sample (track 3 ) is given in figure 2.

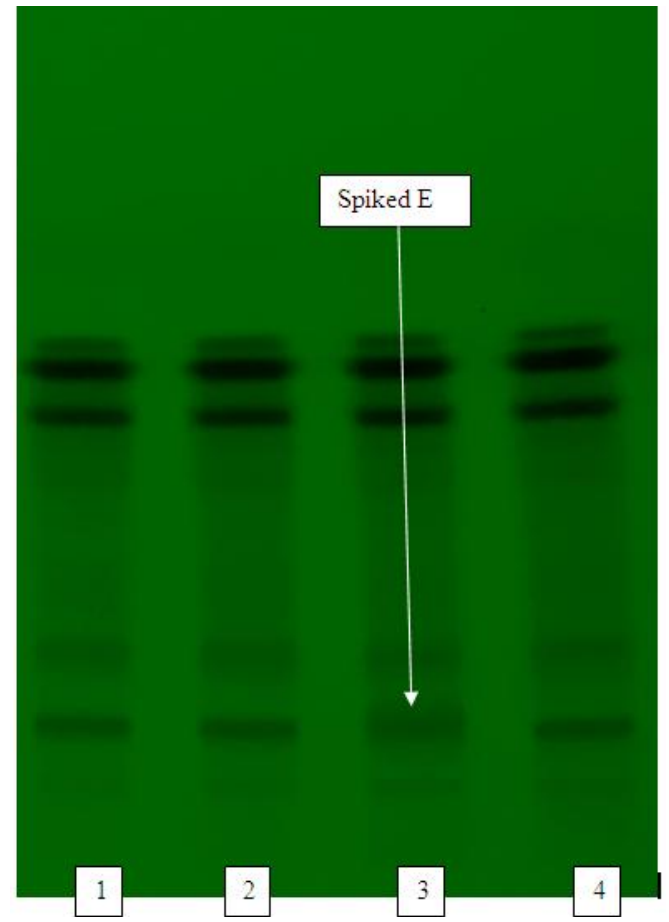

Track 1, 2 \& 4- unspiked sample, track 3- spiked sample, E: Ephedrine Fig. 2: HPTLC fingerprint of unspiked and spiked sample of Balaguloochyadi kashayam (Rajah Ayurveda).

The chromatogram of standard ephedrine, unspiked sample and spiked sample is given in figure 3. Based on the densitometric data of the developed HPTLC method, the ephedrine content in Balaguloochyadi kashayam (Rajah Ayurveda) was found to be $0.2848 \% \mathrm{w} / \mathrm{v}$.

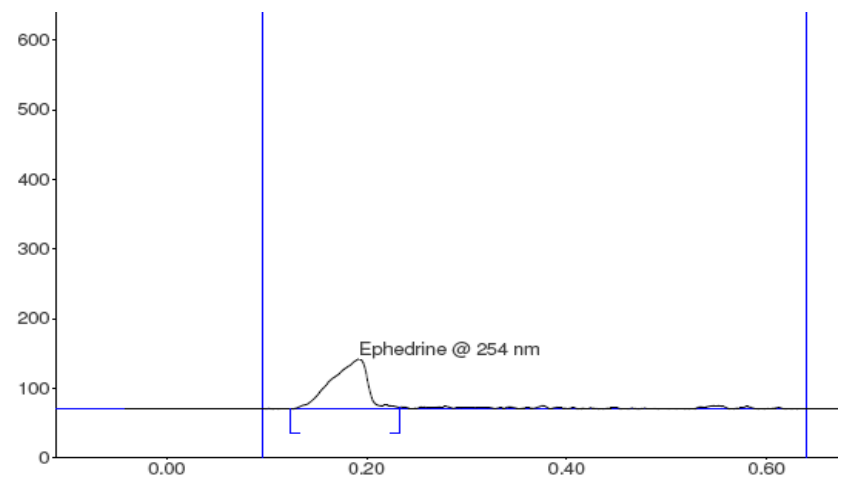

A
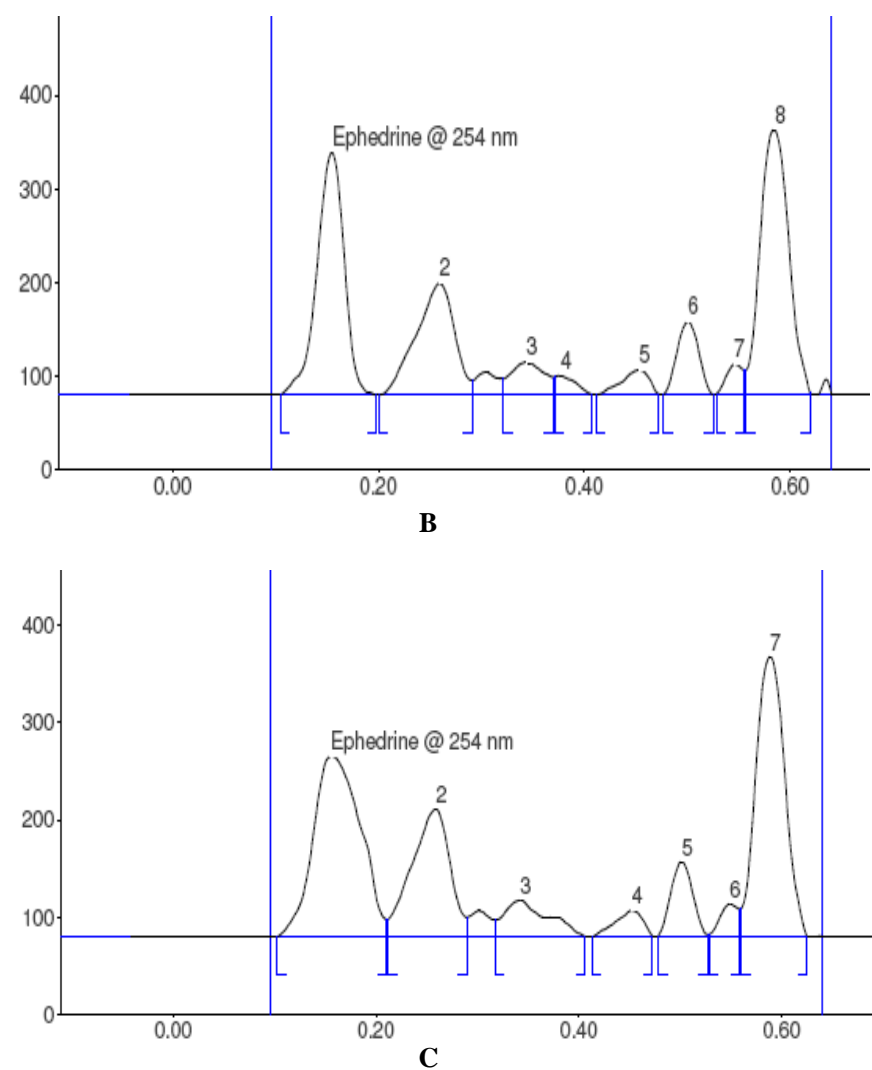

Fig. 3: HPTLC chromatogram of A. standard ephedrine, B. unspiked sample of Balaguloochyadi kashayam (Rajah Ayurveda), C. spiked sample of Balaguloochyadi kashayam (Rajah Ayurveda).

\section{CONCLUSION}

Balaguloochyadi kashayam of Rajah Ayurveda was standardized with respect to physicochemical, microbial and marker-based parameters. A HPTLC method for quantitative determination of ephedrine (chemical marker) present in Bala, major herbal constituent of Balaguloochyadi kashayam was successfully developed and validated. This analytical method and standardization parameters can be used as quality control tool to 
standardise different batches of Balaguloochyadi kashayam formulation.

Financial support and sponsorship: Nil.

Conflict of Interests: There are no conflicts of interest.

\section{REFERENCES}

Gautam V, Raman RMV and Ashish K. Exporting Indian healthcare (Export potential of Ayurveda and Siddha products and services) Road beyond boundaries (The case of selected Indian healthcare systems). Export-Import Bank of India, Mumbai, 2003; 4-54.

Wani MS. Herbal medicine and its standardization. Pharmaceutical Reviews, 2007; 5(6).

Vaidya ADB and Devasagayam TPA. Current status of herbal drugs in India: An overview. J Clin Biochem, 2007; 41(1):1-11.

Kochhar SL. 1981. Tropical crops: A textbook of economy botany. London: Macmillan Pub Ltd.268-71.

Yadav NP and Dixit VK. Recent approaches in herbal drug standardization. Int J Integr Biol, 2008; 2:195-203.

Zafar R, Panwar R and SagarBhanu PS. Herbal drug standardization. The Indian Pharmacist, 2005; 4(36):21-25.

Patra KC, Pareta SK, Harwansh RK and Jayaram Kumar K. Traditional approaches towards standardization of herbal medicines -A review. J Pharm Sci Technol, 2010; 2 (11): 372-379.
Hebbar JV. Ayurvedic medicine information. [ONLINE] Available at: http://ayurmedinfo.com/2012/04/27/balaguluchyadikashayam-benefits-dosage-ingredients-side-effects-reference/ [Accessed 12July 2014]

Available at: http://www.ayurpages.com/balaguluchyadikashayam-indication/[Accessed 12July 2014]

ICH Harmonised Tripartite Guideline- Validation of Analytical Procedures: Text and Methodology Q2 (R1) 2005.[ONLINE] http://www.ich.org/fileadmin/Public_Web_Site/ICH_Products/Guidelines/ Quality/Q2_R1/Step4/Q2_R1_Guideline.pdf

Protocol for testing ayurveda, siddha and unani medicines. Dept. of AYUSH, Ministry of Health \& Family Welfare, Ghaziabad.[ONLINE] Available at http://www.researchgate.net/publication/224944109_Protocol_for_Testing _of_ayurvedic_Siddha_and_Unani_medicines

\section{How to cite this article:}

Khan TA, Mallya R, Gohel A. Standardization of marketed Ayurvedic formulation, Balaguloochyadi kashayamphysicochemical, microbial evaluation and ephedrine content. J App Pharm Sci, 2016; 6 (12): 184-189. 